\title{
Renting an Item to Who Sold It Is It Different from Bay' Al-Wafa' Contract?
}

\author{
RAFIC YUNUS AL-MASRI \\ Islamic Economics Research Centre \\ King Abdulaziz University \\ Jeddah, Saudi Arabia
}

\begin{abstract}
$B a y^{\prime}$ al-wafa' is a contract whereby the owner of an estate (house or land) sells it, with a condition that he will have it back once he returns its price to the buyer (See Articles 118 and 396-403 of Majallat al-Ahkam al-Adliyah). In other words, he who needs cash sells his estate in cash, with the condition that whenever he returns the cash to the buyer, the latter returns to him his estate. Thus, it is a sale contract with an attached condition of abrogation, the seller returns the cash and the buyer returns the estate.

This sale contract has various other names with the Fuqaha' who dealt with it, such as bay' al-'uhdah (custody sale) because both parties pledge to return the substitute or the alternative after a specific period or because the buyer guarantees the item; bay' alidah or bay' al-wa'd (promise sale) because the sale happens as a result of a binding promise instead of a condition; bay' al-amanah (trust sale) because the item sold is entrusted with the buyer; bay' al-nass (people's sale) because people used it frequently and became used to it; al-bay' al-jaa'iz (allowed sale) because some fuqaha' have legitimized it to the point that there is no other contract being legitimized as such and al-bay' al-mu'ad (the retuned sale) because there is a sale and a repurchase. It seems that this kind of sale is as old as the Fifth Century after Hijra.

The people of hiyal (stratagems) have artificially made it a controversial contract: Is it allowed or is it forbidden? Is it a sale or a rahn (mortgage, collateral) for those who allowed it? The reality is that it does not bear any controversy; it is simply a usurious stratagem, i.e. a usurious loan in a form of a sale. There is an amount that is advanced and then returned and the financier benefits from the estate during the period of the loan, either by usage or exploitation. This means that the benefits derived from it are either living in a house, or planting a land. The estate may even be rented out to a third party or to the seller, and the financier benefits from the rent in return for his finance.
\end{abstract}


If the estate was rented out to the seller, this means renting the estate (or selling it on installments) to who sold it in cash. Such renting could be ijarah muntahiya bi altamleek (a renting contract that ends with ownership) or a sale with installments in a form of a sale contract, in other words a sale under the guise of renting. Renting is used here instead of sale with installments so that the seller keeps the ownership of the item, based on guarantee or mortgage/collateral. In fact, this is better for him than the mortgage or the collateral, because in this case the item remains his ownership while in case of mortgage or collateral, the item belongs to the buyer.

This transaction of sale and leaseback is similar to Bay' al-wafa' contract or bay' alistighlal which can be considered as a form of Bay' al-wafa' contract, allowed by some fuqaha', as mentioned earlier, but not by Majma' al-Fiqh al-Islami in Jeddah in 1412AH (1992). Without doubt, the people of stratagems were hoping that it would be allowed. Now, they are trying to allow it under another name. One form of stratagems is to call things with other names that are not relevant, in order to make them acceptable to the public.

Bay' al-Istighlal (the exploitation sale) is to sell an estate with a promise condition, whereby the seller leases out his estate and whenever he pays back the price, he gets back his estate (See article 119 of Majallat al-Ahkam al-Adliyah). It is called Bay' alIstighlal (exploitation sale) because the buyer exploits the estate sold. In other words, he benefits from its rent by way of renting it to the seller. Thus, Bay' al-Istighlal is a form of bay' al-wafa', whereby the estate is leased to the seller. Bay' al-wafa' is itself a form of bay' al-eenah, which is not allowed by the hadith (Musnad Ahmad 2:42, Sunan Abi Dawud 3:274, Nayl al-Awtar 5:233) because the main feature of bay' al-eenah is that the merchandise returns back to the seller. In al-eenah contract, there are two sales in one: one with a spot specific price and the other with a deferred higher price. For example, someone sells an item for SR1000 and buy it back cash for SR900, which means he borrowed SR900 to be repaid SR1000. Thus, the riba in bay' al-eenah is the difference between the two prices. As for $b a y^{\prime} a l$-wafa', riba will arise in the use of the estate involved or its exploitation, as explained above. Riba can arise in a sale or a loan by raising the price for the borrower or by reducing it for the lender, just as riba can arise from a loan for a loan. Imam Ibn Batta reported on the authority of Al-Awza'i that the prophet (pbuh) said: "There will come a time on people where they allow riba contract under sale contract" (Ibn Taymiyyah, 3:130 and Ibn al-Qayyim, 3:178).

The reader might wonder why the contemporary concern in $b a y^{\prime} a l$-wafa', when it is an old sale. The reality is that although it is old, there are many attempts to revive such old contracts, which are no more than stratagems for riba. On $23^{\text {rd }}$ and $24^{\text {th }}$ Shawwal 1424AH (17 $7^{\text {th }}$ and $18^{\text {th }}$ December 2003) a fiqhi seminar was organized in Riyadh where a paper by Nazih Hammad was presented under the title: "Renting the estate to who sold it" as well as four comments. The first was of Siddiq al-Dharir, the second was that of Mughammad Taqi Othmani, the third was by Hussein Hamid Hassan and the fourth by Abdus-Sattar Abu Ghuddah.

Nazih Hammad mentioned in his paper that the earlier scholars disagreed on the legitimacy of renting an estate to who sold it. The majority of scholars do not allow it, in opposition to Malikis and Ibn Taimiyyah from Al-Hanabilah. This is not right 
because what the Malikis and Ibn Taymiyah allowed is: "I sell you my house for such an amount provided that you sell me your animal for such an amount". Two different items are involved here but in our case, we are talking about one item that returns back to the seller. It goes on cash sale and come back on installment or on Ijarah muntahiya bittamlik. This is similar to the prohibited bay' al-eenah. So, it is not true as Nazih Hammad claims that the allowance of this contract applies to the case under discussion. Siddiq al-Dharir agreed with him but based his argument on the principle of natural permissibility of things, even concerning compound contracts which are made up of more than one contract, each of which may be permitted on its own but not allowed when put together in one contract, such as sale and loan in one contract.

With this, Dharir contradicted his saying, in his book Al-Gharar (1967, p.98): "I believe that the approach of the Islamic jurisprudence realizes the stability of transactions, by emphasizing the principle of not allowing the multiplicity of contracts in one and making it a basic rule". The basic rule for him, then, was the prohibition of multiple contracts in one transaction.

Both Osmani and Abu Ghuddah confirmed in their comments on Hammad that many Shari'ah councils believe that al-eenah disappears with time: a year, in which market changes occur (price changes). This is hard to digest! Where does this year come from? Besides, market changes can happen anytime.

Hammad discussed the renting ending with ownership of the estate to who sold it and allowed it on the basis of the restrictions of Majma' al-figh al-Islami 2000. But by looking at these restrictions, especially number one and two, I believe that they are theoretical restrictions that cannot be realized in practice. The actual realization of these restrictions means it would no longer be an ijarah muntahiyah bi-al-tamleek (renting leading to ownership). This is what can also be taken against the comment of Hussein Hamed Hassan. It seems to me that this kind of approach in issuing fatwa is like holding the stick in the middle. If it passes, the mufti would say: did I not tell you? But if it does not, he would claim that the conditions were not met.

What is important is that renting the estate to who sold it is a stratagem in order to get around the prohibition of bay' al-wafa' (promise sale) by Majma' al-fiqh al-Islami, giving it a different new name among the many new names given to this contract, which can also be considered as a form of bay' al-eenah. Branches of Islamic banks and windows of conventional banks should avoid and refrain from the use of such compound contracts which lead to sale and loan or mutual loans or eenah or tawarruq (especially if it is in a form of eenah but under the name of tawarruq) or similar contracts such as bay' al-wafa' (promise sale) or bay' al-istighlal (exploitation sale) or any of the old and well-known riba based stratagems.

I had made it clear earlier and warned against such practices in a verbal intervention in the first seminar of Dallah Al-Barakah held in Madinah in 1403AH. Al-eenah and tawarruq are compound contracts. If the rule concerning the 'simple single contract' is the permissibility, the rule concerning the compound contracts (multiple contract in one) is the prohibition. This is based on the hadith of the Prophet (pbuh) which prohibits two sale contracts in one and two transactions in one. The promise, if not binding and was 
jointed to a contract, this does not make the contract a compound one. However, if it is binding, then it becomes a condition that leads to the compounding of the contract. It is well known that a condition changes the ruling. For instance, a non-conditional riba is allowed but a conditional riba is not, and if someone lends someone an amount without condition and later borrowed from him, this is allowed but if he lends him on the condition that the latter lends back, this is not permissible.

It is important to note that the secular laws which allowed "the promise sale" cancelled it later when they allowed lending at interest because there was no longer any need for it. This is another proof that the promise sale and similar contracts are but means and excuses to justify riba loan, hidden under the guise of sale. The way out of this "promise sale" is that the seller sells definitely his estate in cash without any condition attached to it and when he has the means to buy it back at the market price he can do so.

I wonder about the fiqhi mentality that propagates the prohibition of riba and yet goes on allowing it at higher rates, under various pretexts and stratagems. This is like closing the "white" door and opening tens of "black" windows, to the point where the ijtihad of contemporary fuqaha', if we can call it ijtihad, focuses on no other than the inherited old stratagems. It seems that the whole of fiqh has been reduced to mere stratagems. Without doubts such stratagems make the banking operations more costly, complex and ambiguous. Ayub al-Sukhtiani commented by saying: "had they faced it, i.e. came to it through its door, it would have been much more easier" (Bayan al-daleel fi Butlan al-tahleel, p.374). Ibn Taimiyah says: "The clear cut riba is more beneficial to them than these stratagems. The legislator is wise and merciful, He does not prohibit what is beneficial and allows what is less beneficial, He does not prohibit what is harmful and allows what is even more harmful. If he has prohibited such transactions, then his prohibition of these transactions (stratagems) is even stricter". If it happened that he has allowed it, then the permission of clear riba would have been more acceptable" (ibid). Ibn al-Qayyim says: "Our Sheikh (Ibn Taimiyah) used to prohibit the issue of tawarruq. He was asked many times to review his decision, while I was in his presence, but he never did and he said: "the reason why riba was prohibited exists in it with the extra cost of buying a commodity and selling it at loss. Shari'ah does not prohibit a lower harm (riba) and allows what is more harmful (al-tawarruq)" (I'lam alMuwaqqi'een, 3:182).

\section{References}

Abu Dawud (n.d.) Sunan, Dar Ihya' Al-Sunnah Al-Nabawiyah, Cairo.

Ahmad, Al-Imam (1398) Musnad, Al-Maktab Al-Islami, Beirut.

Al-Dharir, Siddiq (1386) Al-Gharar Wa Atharuhu fi'l 'Uqud, n.p., Cairo.

Hammad, Nazih (1424) Ijarat Al-Ain Liman Ba'aha, paper presented to the Al-Rajhi Fiqh Seminar, $23^{\text {rd }}$ and $24^{\text {th }}$ Shawwal 1424AH, Riyadh,

Ibn Al-Qayyim (1374) I'lam al-Muwaqqi'een, Al-Maktabah Al-Tijariyah Al-Kubra, Cairo.

Ibn Taimiyah (1416) Bayan al-Tadleel fi Butlan al-Tahleel, Maktabat Leena, Damanhoor, Egypt.

Ibn Taimiyah (n.d.) Al-Fatawa, Dar Al-Ma'rifa, Beirut.

Majallat al-Ahkam al-Adliyah (1349), Sharh Al-Atasi, n.p. Hims (Syria).

Majma' Al-Fiqh Al-Islami, Al-Majallah, Issue 7, vol. 3, Jeddah.

Al-Shawkani (n.d.) Nayl Al-Awtar, Maktabat Al-Babi Al-Halabi, Cairo. 